\title{
The disparagement of pain: Social influences on medical thinking
}

\author{
Harold Merskey DM FRCP ${ }^{1}$, Robert W Teasell MD FRCPC ${ }^{2}$
}

H Merskey, RW Teasell.

The disparagement of pain: Social influences on medical thinking.

Pain Res Manage 2000;5(4):259-270.

Patients with pain often feel that their suffering is taken lightly, dismissed or denied. Before the introduction of anesthesia, pain was regarded as an awful affliction. This view diminished somewhat once anesthesia became available, although it still holds true for some forms of pain, eg, pain associated with terminal cancer.

Pain was then treated as less troublesome when it became a reason for disability compensation to be paid. Examples are given of the disparagement of complaints by individuals reporting pain in the past 150 years. Factors that encourage doctors to underestimate patients' pain include the requirement for doctors to control the issue of narcotics; circumstances in which patients may benefit from compensation by claiming that their pain is great; and the development of attitudes that understate the importance of the relief of pain and overstate the importance of activity, exercise and not complaining. Current attitudes in this respect are associated with the insurance industry, but it has been shown that, even patients who do not have a compensable injury or have pain that is not disabling fail to receive the treatment for pain that is appropriate, eg, postoperatively. The present paper reviews and discusses these problems and suggests that disparagement of pain and disability in the medicolegal field also leads to the rejection of pain in other contexts.

Key Words: Disparagement; Pain; Social influences

\section{Le dénigrement de la douleur : Influences sociale sur la pensée médicale}

RÉSUMÉ : Les patients qui souffrent sont nombreux à trouver qu'on prend leur douleur à la légère et qu'on l'écarte du revers de la main. Avant l'introduction de l'anesthésie, la douleur était considérée comme une énorme épreuve. Cette perception s'est quelque peu atténuée après l'avènement de l'anesthésie, bien qu'elle n'ait pas changé pour certaines formes de douleurs, par exemple la douleur associée au cancer terminal. La douleur a ensuite perdu de son importance lorsqu'elle est devenue une raison de verser des prestations d'invalidité. On donne ici des exemples où les plaintes formulées par des individus souffrants au cours des 150 dernières années ont été dénigrées. Les facteurs qui encouragent les médecins à sous-estimer la douleur de leurs patients sont, notamment, le devoir de contrôler les narcotiques, les circonstances dans lesquelles les patients peuvent bénéficier d'indemnisations sous prétexte que leur douleur est trop grande et la mise en place d'habitudes qui sous-estiment l'importance de soulager la douleur et surestiment l'importance de l'activité, de l'exercice et du stoïcisme. De nos jours, les attitudes à cet égard sont gouvernées par l'industrie de l'assurance, mais on a démontré que même chez les patients qui ne souffrent pas de préjudices justifiant des indemnisations ou qui souffrent sans être invalides ne reçoivent pas le traitement analgésique approprié, par exemple, après une chirurgie. Le présent article passe en revue ces problèmes, en discute et affirme que le dénigrement de la douleur et de l'invalidité dans le domaine médicolégal entraîne également le rejet de la douleur dans d'autres contextes. 
Why do people not believe me? Why do I have to prove I have pain? (Mrs R, 1989)

\section{Citoyens,}

Je viens vous entretenir un moment d'un de vos ennemis; de l'éternel ennemi du genre humain; d'un tyran qui frappe, avec une égale cruauté, l'enfance et la vieillesse; la foiblesse et la force; qui ne respecte ni les talens, ni les rangs; qui n'est jamais attendri par le sexe ou par l'âge; qui n'a point d'amis à épargner, point d'esclaves à ménager; qui frappe sa victime au milieu de ses amis, dans le sein des plaisirs, et sans craindre l'éclat du jour plus que le silence des nuits; contre qui la prévoyance est vaine, et la défense d'autant moins sûre, qu'il semble $s$ 'armer contre nous de toutes les forces de sa nature.

\section{Citizens,}

I am about to talk to you about one of your enemies; the eternal enemy of the human race, a tyrant who strikes with equal cruelty in infancy and in old age, weakness and strength; who respects neither talent nor rank; who is never moved either by sex or by age; who has no friends to spare, no slaves to conserve; who strikes his victim in the midst of his friends in the heart of his pleasures and without fearing the thunder burst of the day more than the silence of the night; against whom foresight is useless, and defence so much less safe that he seems to have armed himself against us with all the powers of his nature.

(MA Petit, Discours sur la Douleur, Delivered at the opening of the course in anatomy \& surgery for the General Hospital of Lyon [November 19, 1799])

$\mathrm{T}$ he source of the first quote is a lady who sustained a cervical flexion extension injury (whiplash). A few weeks after receiving the injury, she still could not sleep because of pain and began to experience unpleasant thoughts such as the one cited above. A variety of opinions had been offered, including that she had hysteria - a scenario that is repeatedly played out across the world. Six years later, a supraclavicular approach at operation to relieve a thoracic outlet syndrome showed that she had severe fibrosis around the brachial plexus, presumably attributable to ruptured muscle fibres and bleeding at the time of the accident.

These two quotations suggest that, despite or as a consequence of the fact that we can often relieve pain more than in the 18th century, we respect the patient with pain less.

\section{PAIN AND ANESTHESIA}

Before the introduction of anesthesia, pain was seen as a terrible affliction. The lecture by Petit goes on in the same vein, as his remarks quoted above describe the extreme nature of the experience of pain. Fanny Burney, an English woman married to the Marquis d'Arblay, was a novelist and journalist who described her own mastectomy undertaken by Baron
Larré, the Napoleonic surgeon, some months after the commencement in August 1810 of pain in the breast when she was 36 years old. She delayed seeking treatment for a little while, the pains got worse, her concerned husband urged her to have treatment, and ultimately, after hesitations and consultations, she accepted operation on October 30, 1811. The description of her hesitations and her experiences makes it plain that the pain of surgery was an exceptional experience for which (even though a novelist and journalist) she could not find adequate words (1).

Pictorial records of the agony endured in operations before the advent of anesthesia (2) did not spare the horror. Despite the unpleasantness of operations, they were undertaken, at times, for the relief of pain, as for example tic douleureux, even with cutting of the facial nerve (3).

Rey (4) makes it clear, as does casual knowledge, that different attitudes toward pain have been maintained over the centuries for philosophical, religious or cultural reasons. Whether it was punishment, as the Greek (poine) and Latin (poena) words mean, or whether it was thought to be an action of demons, or whatever other explanation, pain was most often seen as the greatest problem for humankind. The exception would only be those, such as the Stoics, who perhaps made overcoming pain by mental power the greatest potential psychological achievement of humans.

After the advent of anesthesia, many of the terrors of pain were removed, and because this severe nociceptive iatrogenic pain was much more controllable, pain at large seems to have lost some of its traditional fear and dread.

\section{ANOTHER IMPRESSION}

Although the awful nature of severe pain is commonly recognized, acceptance by doctors of its tremendous impact does not seem to be as strong in modern times as it was before the introduction of anesthesia. Loss of familiarity with the worst cases of pain might be blamed for this, but it is also widely noticed that doctors do not appear to treat pain as seriously as might be expected. They often do not seem to provide the care that it is frequently thought to deserve, and do not seem to recognize the patient's degree of suffering or its impact on the sufferers. Indeed, regular protests appear from time to time from different sources to the effect that pain is not being properly managed.

The Royal College of Surgeons (RCS) of England and the College of Anaesthetists established a Working Party, which reported in 1990 that the treatment of pain after surgery in British hospitals "...has been inadequate and has not advanced significantly for many years" (5). Fourteen papers from Britain, Australia, Scandinavia and the United States, published between 1952 and 1990, were cited, demonstrating the following.

\section{A significant number of patients experience an unacceptable degree of pain after surgery when it is treated with conventional intramuscular opioid therapy. There has been no apparent improvement since the first study in 1952. (5)}


At that time, $31 \%$ to $75 \%$ of patients were considered to have either 'insufficient analgesia' or 'moderate or severe pain'. The largest reported percentage (6) was $75 \%$; the most recent study in the review (7) reported $37 \%$, and the earliest (8) reported $33 \%$. The mode was $33 \%$. It seemed that matters had not changed over 38 years.

In accordance with conventional views, the RCS report states that the site and nature of surgery influence pain, and that psychological and sociocultural factors may be relevant. For example, cultural background; past experience; the meaning of pain, fear and anxiety; the ability to control events; and coping strategies can all affect the symptoms (5). Such factors help account for individual differences in response to pain and for the sometimes poor correlation between injury and pain. Cultural norms regarding behaviour when in pain, and when and where to express pain are also invoked, as are the attitudes of the nursing and medical staff, responses of other patients and the ward environment (9).

Perhaps two important factors in the attitude of medical and nursing staff deserve to be mentioned because they do not appear to be cited often, although there is a prima facie case that they ought to be emphasized. The first is simply the traditional hierarchy of medical priorities. To the patient, pain is an immediate and urgent priority. To the doctor, there can be no priority higher than finding out the nature of the problem, if at all possible, before treating it. The comfort of the professional depends on knowing what to do, and this most of all requires understanding probable causes before treatments are applied. In contrast, patients often come to the doctor secondarily for explanations and primarily for relief. It is not justifiable that pain be neglected, and yet it is frequently inevitable because of these different hierarchies.

The second major contributing factor in diminishing the active interest of doctors and nurses in treating pain is their training. The treatment of pain frequently gets relegated to second place once a patient ceases to have an identifiable problem with an identifiable cause. True, a classic aphorism advises that the function of the physician should be "To cure sometimes, to relieve often, to comfort always", but it probably takes second place to a modern version that might be expressed as, "To diagnose always, to cure often, to relieve sometimes". Cassell (10) more cynically expressed it as, "no cause, no relief, no problem". Inadvertently, medical training, which tends to compartmentalize medical conditions on the basis of pathophysiological diagnoses, promotes this modern version.

The Report of the Commission of the Royal College of Surgeons and the College of Anesthetists (5) stated that the following misconceptions were connected with the failure to relieve pain.

- The doctor and nurse believe that they, rather than the patient, are the authority on the patient's pain.

- Comparable physical stimuli produce comparable severity of pain in different people and, similarly, equal doses of analgesics produce equal outcome for all people.
- Physical signs, physiological or behavioural, accompany pain and can be used to verify its existence and severity.

- Postoperative pain cannot be prevented.

Pharmacokinetic factors, lack of knowledge of the extent to which opioids may properly be used, inappropriate fears of opioid addiction, lack of knowledge about pain assessment and narcotic administration (11), a failure by nurses to ask patients whether they are obtaining adequate relief, and time needed to administer opioids because of checking procedures required have all been said to contribute to the failure to treat pain adequately, particularly postoperative pain. We suggest that it boils down to attitudes that do not properly emphasize the need to treat pain more seriously, and competition between tasks for the available time. Nurses are overstretched in many hospital centres in Canada and the United Kingdom, and in many public hospital services in the United States, as in Britain and Canada. When vital functions need first attention and there is no time left, pain goes unrelieved.

Even among pain conditions there is a hierarchy with respect to pain. Staats (12) observed that cancer and noncancer pain are treated differently. The rationale for this difference in treatment is not based on the fact that the complaints of pain are different or that the underlying pathophysiological states are necessarily treatable. It is not clear that the pain of nociception associated with cancer is different from the pain experienced in nonmalignant pain states. Pain is defined by the International Association for the Study of Pain (IASP) as "an unpleasant sensory and emotional experience associated with actual or potential tissue damage, or described in terms of such damage" (13). As Staats (12) points out, the definition does not state whether one pathological condition makes pain any less a source of suffering than another pathogenesis.

Staats (12) noted that, with cancer pain patients, the cause of disease is relatively straightforward, and easily visualized and diagnosed. Therefore, it is assumed that when a cancer patient reports pain, the report of the pain is tied directly to the known disease state and that the patient's report of pain is accepted as an accurate reflection of nociception (14). It was also noted that this assumption remains common despite the known negative emotional state associated with cancer pain (15). Staats (12) points out that, in contrast, nonmalignant pain "is treated with a bias against biomedical therapies, and the underlying biologic etiology is frequently overlooked or minimized". Bias develops from the physician's inability to identify clearly the biological sources of many nonmalignant pains, the high incidence of morbid psychiatric disorders, and the success of some psychiatric and psychological treatments; albeit the well established effectiveness of amitriptyline in a number of conditions may often be related to its analgesic effects rather than to antidepressant actions, as shown first by Watson et al (16).

While all these may be weighty and serious factors that contribute to failures to treat pain in hospital, there is a much broader and more contentious aspect that extends beyond the hospital or family practice. 


\section{THE EMERGENCE OF NEGATIVE ATTITUDES}

Post-traumatic pain: Different attitudes toward pain began to emerge when it became an issue in compensation claims. With the rapid growth of railways in the 19th century, accidents, combined with legislation for compensation, inevitably occurred and led to frequent claims for compensation. The view that patients could sustain "concussion of the spine", with significant pain therefrom and few external signs of injury, was espoused by Sir John Eric Erichsen in 1867 (17) and subsequently expanded (18). He attributed painful symptoms following these events to damage to the spinal cord by concussion. This became part of a general view that some type of disturbance to the nervous system might be physically produced without hemorrhage, either by temporary disablement of cells, or perhaps by the disruption of their connections. While many of the cases described by Erichsen reflect paralysis of one or more limbs, or even paraplegia, he also remarks that "Pain and perverted sensations of all kinds are very common in cases of spinal concussion from direct blows on the back" (18). These effects were seen to be due to the remote consequences of the blows to the spine.

\section{They consist of pain in some part or parts of the spine, greatly increased by pressure and motion, associated with reflex rigidity of the muscles of the back, the patient moving the vertebral column as a whole. The pain is greatly increased by all movements but especially by those of rotation...Pain frequently extends down the limbs or around the body, giving the sensation of a cord tied tightly.}

Difficulties in moving the head were noted. Erichsen favoured an inflammatory explanation for the pain, the inflammation being presumed to affect the spinal cord.

Erichsen's views were challenged by Page (19), who was a surgeon to the London and Northwestern Railway Company, and who argued that many of the consequences that were dwelt upon by Erichsen were attributable to 'nervous shock'. By this, he meant that fright was a potent cause of the symptoms. In men "...the frequency of hysteria... (if such a term may be used in men) is not fully recognized". In saying this, he was relying on the observations of an earlier author, Mr Furneaux Jordan, as well as on his own observations. Page opposed Erichsen in his attribution of organic causes in many of the patients, although he recognized a large number of organic lesions as being relevant also. He observed that Erichsen often dwelt on 'concussion', where overt spinal damage or neural disease could be shown, and mixed that with discussion of the cases where those changes could not be shown. He noted the infrequency of postmortems, confirming Erichsen's theories in patients who were not directly injured, and held that " .... secondary and remote degeneration of the spinal cord in cases where there has been no definitive evidence of injury, is very rare indeed". Arguments such as the latter are echoed today in phrases that may be found stating that there was no neurological disorder, no evidence of permanent injury, no sign of inflammation etc, but Page was only mildly aggressive in his writing about Erichsen and was ready to accept that, even if physical damage had not occurred, fright could have genuinely troublesome effects.

The alternative approach that Page recommended relied on the notions of 'general nervous shock', 'hysteria' and 'malingering'. The notions of hysteria in particular had been developed both in Britain and France in the 1860s and 1870s. Also in connection with injury (but not railway injury) Sir John Russell Reynolds (20) described three cases of paralysis "dependent upon idea", and Charcot (21) picked up this notion.

Charcot (21) liked the ideas of Russell Reynolds and stated that the idea of paralyses from thoughts had long been known, but only Reynolds had studied them in a methodical and systematic way. He later decided that hysteria in the male was not so rare as was thought, and observed the following.
Quite recently male hysteria has been studied by
Messrs. Putnam and Walton in America, principally
as it occurs after injuries, and especially after
railway accidents. They have recognized, like Mr.
Page, who in England has also paid attention to this
subject, that many of these nervous accidents
described under the name of railway accidents, and
which according to them would be better described
as Railway-brain, are in fact, whether occurring in
man or woman, simply manifestations of hysteria.

He went on:

\section{The victims of railway accidents naturally demand damages from the companies. They go to law; millions of dollars are in the scale. Now I repeat it is frequently hysteria which is the agent in these cases.}

Charcot (22) had noted that serious and obstinate cases after collision of this kind rendered their victims incapable of working "or paying any attention to their avocations for many months, or even many years, [they] are very often hysteria, nothing but hysteria". With surprising optimism, he then went on to say that the importance of the cases would perhaps tend to "....remove the discredit which is still, even in the present day attached, from deeply rooted prejudice to the word hysteria - a circumstance which renders our task the more difficult".

It is evident that, although Charcot was rescuing the bona fides of the patients, he was, at the same time, like Page, opening up their cases to less sympathetic treatment than if he had adopted the views of Erichsen in regard to organic causation.

In Germany, Oppenheim (23) supported the ideas of Erichsen and also developed the idea of a category of "traumatic neurosis' for conditions following railway accidents. Although the possibility of malingering was recognized by Erichsen, he dismissed the topic, suggesting that, if care was exercised, no one would be deceived. But he claimed that, of 234 cases of his own, 32 were cases of fraud or willful exaggeration. 


\section{WORKMAN'S COMPENSATION}

Trimble (24) pointed out that, in Britain, the Employer's Liability Act, passed in 1880, provided for compensation to 'workmen' who received injury during the course of their employment, provided that the injury was not the direct result of negligence on the part of the workers themselves. The powers were considerably extended in 1906 by the Workman's Compensation Act. In the first six years after the 1906 Act, the actual numbers of accidents reported in industry rose $44 \%$ from 326,701 to 472,408 , despite that the number of people at work remained the same (24). Compensation went up by $63.5 \%$ from $£ 2,055,370$ to $£ 3,361,650$. A Home Office Report in 1912 suggested that it was directly due to the workmen who previously would have continued to work but stayed away for the same injuries.

By this time, a view that motivation and malingering contributed largely to claims of injury under Workmen's Compensation Acts was becoming popular among physicians.

Various forms of employers' liability dated well back into the 19th century, but many of the issues connected with compensation were well known by the time Collie (25) published the first edition of his book on Workman's Compensation in 1912. Collie was a medical examiner and medical officer for large metropolitan utilities and for the London County Council, among others. He published a table relating to 9388 official examinations of 4965 employees. One thousand and two were found by him to be fit for duty forthwith, 2998 received short periods of further leave and 239 were found to be 'out and out malingerers'; 726 were permanently unfit or 'died soon after medical examination'. However, although some $80 \%$ were thus found to be 'genuine', and far fewer were malingerers, the burden of the medical section of his book (which also has a detailed discussion of legal issues) was to present case after case where he considered he had unmasked fundamentally false claims, such as the following.

\section{Sir John, having examined an employee who had been sick for four weeks and complained of an injured knee, with no abnormality being found, measured the knee and sent him out to walk for two hours. No swelling was discovered by measurement on his return and he was told to resume work forthwith, which he did.}

Sir John was also fond of using an electric battery. He reports a popular erroneous notion that any spinal injury was liable to be associated with impaired sensation and used a noisy electric battery machine to trick workers into saying there was pain from stimuli when the power had been turned off but the noise continued, or gave them increasingly strong shocks as long as they denied pain in an area. He did volunteer that return to work should be gradual in those who have been off for some time, and that it was inhumane during World War I to force cowardly malingerers to serve in the front line. Only one mistaken diagnosis of malingering is mentioned by him - and that was not his.

\section{COMPENSATION AT LARGE: TREATING PATIENTS WITH HOSTILITY}

After the rather large diversion of World War I, compensation for the injured was held to be necessary and was also somewhat uncertain. In 1939, Kennedy (26), a transplanted Englishman in New York, wrote the famous erroneous line about compensation neurosis, echoed by Miller in 1961 (27), that it was "....a state of mind, borne out of fear, kept alive by avarice, stimulated by lawyers, and cured by a verdict". Mendelson (28), in a notable paper entitled "Not "cured by a verdict'", demonstrated that, of 10 studies since World War II in the English language literature, not one had supported Miller's claims, apart from Miller's own work as an examiner for insurance companies.

Much cogent literature exists to refute Miller's claims on other grounds. The recognition of neuroplasticity; the demonstration by Barnsley et al (29), Lord et al (30) and Wallis et al (31) of the part played by facet joints and intradiscal rupture in many cases of postmotor vehicle accident cervical pain or in so-called nonspecific low back pain; and an accumulation of other information have continued to be denied for various reasons, most of which seem to rely on assuming money to be the basis for the complaint.

One can read today comments by medical examiners not less arbitrary or one-sided than the comments of Sir John Collie, such as, "Whether she chooses to work or not is her own choice", which was said almost routinely of individuals by one particular examiner. Or

\section{...if he holds himself as tight as he was during my examination, he will in fact self-induce symptoms of aching in his muscles. I would therefore conclude that a good deal of his symptomatology at this point in time is exaggerated.}

Most notably, a task force of the IASP (32) took the view that, after six weeks, patients with so-called nonspecific low back pain who lacked radiological evidence of their condition should not even be labelled as experiencing pain but rather their condition should be referred to as 'activity intolerance'. In addition, they should cease to receive medical benefits but should be reclassified as unemployed (albeit perhaps with some intention to provide rehabilitation, if possible).

Of a patient who needed help to clean her perineum, one defence examiner made the following argument.

\section{Sacrificing one's personal privacy in matters of hygiene, unnecessarily, would seem to represent a circumstance of an extraordinarily needy individual.}

In another case, "His pain complaints are exaggerated I expect [sic]", while with respect to acceptance of the patient's complaints it was alleged that “....such statements can only encourage illness behaviour and the hope of compensation", supposedly because the natural history of soft tissue injuries is alleged to be one of rapid recovery in the absence of medicolegal or insurance issues. (The latter based on reference to a seriously flawed article [33] that lacked the power $\mathrm{ab}$ initio to demonstrate the claim made). 
Assertions of this type, repeatedly made with or without evidence, are bound to have an impact on the thinking of medical practitioners who may be on the sidelines in the debate, and who will temper their acceptance of the patient's pain - even when independence exists - by giving credence to the statements for money that are made by defence medical examiners about the financial interests of the patients.

A 30-year-old woman was seen three years after receiving an injury to her shoulder, neck and adjoining soft tissues. She was forced to leap from a moving farm vehicle that had gotten out of control. She held on to her two-year old child with one arm, and subsequently landed on the other arm. She suffered severe head, cervical, upper limb, thoracic and lumbar complaints at that time. She had a 'stellar' work record before her injury and had returned to work part-time thereafter. She then ran foul of at least two major problems. First, her memory was not as good at carrying and retaining information as previously, and second, her physical endurance was markedly limited due to pain and sleep disturbance. She showed no signs of lack of courage or determination. Her past history and place of work were organized very methodically and comprehensively.

A physical medicine specialist who was asked to see this patient wrote as follows after arguing that a 'nonorganic chronic pain state' should not be recognized as resulting from a sprain or strain type injury.

\section{It is unfortunate if that attribution is accepted, it is generally accepted [sic] that they result from multiple psychological/emotional/social stressors and failure to recognize and identify the stressors and manage them appropriately, dooms the patient to perpetuation and indeed propagation of their chronic pain states...}

There is no warrant in the literature for saying that it is generally accepted that multiple psychological/emotional/social stressors influence pain in a particular case, without qualifying this statement severely. Individual stressors may influence individual pains, but any time that pain is rejected on the grounds of psychological causation, much more work has to be done by way of proof than has been acknowledged to date.

After noting that the patient had attempted suicide in October 1997, the same physician went on to write as follows.

As has previously been noted, there is no objective clinical evidence to indicate an ongoing organic pathology which would otherwise preclude a return to normal function and activity. Continuing perceived disability relates to Ms. X's subjective complaints of pain. Continued acceptance of those perceived limitations, whilst perhaps being the 'sympathetic' approach is not in the patient's best interest [sic]. Over three years has not resulted [sic] in any improvement in the patient's pain, nor her level of function. It is therefore a destructive 'malignant' process.
This physician also made the following argument.
Once the stressors have been identified and management undertaken, then there has to be the appropriate behavioural modification, generally under the supervision of a clinical psychologist...in behavioural modification techniques.

The above argument is topsy-turvy. Specific evidence is not brought forward nor relied upon. The absence of structural abnormalities is taken as proof that a disease process is absent. Symptoms are then 'explained' with the help of psychiatry, without internal justification. This physician went on to recommend a psychological assessment, history-taking, identification of the stressors with appropriate behavioural modification, and an incremental reconditioning program. Moreover, being 'sympathetic' with regard to the patient's pain because significant recovery was not seen is now regarded as a destructive and malignant process. Even 'sympathy', the bare minimum a doctor or other health care professional can offer the pain patient, is considered toxic.

It is amazing, considering how little was accepted that was put forward by others, how much was put forward without evidence.

A second expert in physical medicine commented as follows regarding the same patient. "...a review of the mental state involves complaints of chronic pain, increasing dysfunction and ultimate...depression". It was argued that there was no suggestion in documentation from an emergency room report that the patient had sustained any significant injury to the left shoulder, left buttock or left thigh, but nevertheless she went on to complain.

The following was said about our patient.

\begin{abstract}
It would not only be safe but also in the patient's long-term interest to return to gainful employment. A fully coordinated functional restoration program has been recommended ... However in the present case, a decision to remain dysfunctional cannot be confused with a formal Disability or Handicap.
\end{abstract}

Here we see the medical profession, or at least a busy and financially successful part of it, engaged in the denial and cost containment of claims for pain, no matter how serious the illness affecting them may have been.

\section{RESTRICTION OF TREATMENT}

Attempts to treat pain fully are frequently lacking. Melzack (34) provided an important review of this topic in his address as president to the Vth World Congress of the IASP. He pointed out that the available studies indicated that children experienced the same qualities and intensities of pain felt by adults $(35,36)$ but that they are substantially undermedicated. In a study by Eland and Anderson (37), more than $50 \%$ of children who underwent major surgery - including limb amputation, excision of a cancerous neck mass and heart surgery - were not given any analgesics, and the remainder received inadequate doses. Beyer et al (38) followed 50 children and 50 adults after heart surgery and found that children 
received $30 \%$ of the analgesic doses compared with $70 \%$ given to adults, and six children received no analgesics during the first three days after surgery. In more routine medical problems (39), random samples of 90 children and 90 adults, matched with appendicectomies, hernias, fractures and burns, the children received one-half to one-third of the number of doses of narcotic drugs given to the adults.

Melzack (34) drew attention to information about postoperative pain being inadequately treated, to burn pain being extremely high, and to the routine suffering of 30 consecutive patients during debridement and physiotherapy (40). He pointed out that even cancer pain has been poorly controlled, despite the availability of medication (41), although matters appear to have improved somewhat.

As Melzack also pointed out, at that time it appeared to be difficult for patients with chronic noncancer pain to obtain adequate treatment with opioids. Evidence was brought forward 18 years ago by Taub (42) - and a little more recently by Portenoy and Foley (43), Zenz et al (44) and Portenoy (45) - that it was possible to use narcotic drugs effectively to treat many patients with chronic pain who do not have psychological problems or a history of drug abuse. Yet, medical regulatory bodies such as the Colleges of Physicians and Surgeons in Canada and the Federation of State Medical Examining Boards in the United States have only very recently begun to accept the relevance and usefulness of substantial use of narcotic drugs for patients who have chronic noncancer pain. This has been thoroughly discussed in this journal and need not be repeated, except to point out that the Federation of State Medical Boards of the United States (46) has adopted a policy, much like the recommendations of the Canadian Pain Society, that is recommended to all the individual states (47).

The reversal of opinion on the broader use of opioids reinstates some beneficent attitudes that were abandoned when restrictive views became prevalent as the gradual introduction of controls over opioid substances took place, at least in English-speaking countries, in the 19th and 20th centuries. It has been customary to think of the 19th century as a period in which abuses of opium were widespread and common, leading to the development of regulations limiting their use to medical needs. The stereotype of oriental opium dens and lives wasted in chronic indulgence in opium is linked to the 19th century, but the evidence that such phenomena were major factors in society, or that the abuse of opium was a widespread and dangerous problem is small (48). Widespread use of opium in 19th century Britain produced a quota of reports of cases of harm, and seemingly much more indication of regular use of opium both for medicine and for leisure by all classes. The accidental death of babies who were given too much sedation with opium medicines was a cause for concern, as well, as one might suppose, as the purposeful use of potentially lethal quantities in ending the lives of unwanted babies placed in 'baby farms', where they were fed insufficient food and too much narcotic (49).

The effect on infant mortality of some rather feeble regulations in the United Kingdom 1868 Pharmacy Act was pur- portedly to change the United Kingdom opium-related death rate among children under five years of age from 20.5/million before the Act to 12.7/million two years later (48) - a figure that may well not be meaningful and is anyhow small. By contrast, suicide rates in Western countries are thought to be low when at $12 / 100,000$, and high when at 17 or $18 / 100,000$ and above.

The larger function and intention of the Pharmacy Act appeared to be to give power to professionals, doctors and pharmacists to intervene in the use of a widespread commodity, sold until then by anyone from shoemakers to corner stores, as Berridge and Edwards (48) have shown; the medical profession ultimately became established as the arbiter of dispensing by government action through legislation. In effect, this gave the decision to the physician alone as to who might or might not have pain and who was worthy of treatment.

It is a short step next to devaluing the need of anyone who seems to be contumacious, demanding, lily-livered or, even worse, laying claim to suffering without dependable 'objective' evidence of its cause, while seeking a controlled substance that might be used for illegitimate pleasure.

Placed in this position, doctors saw themselves as liable to be deceived - not to say fooled - and became at risk of responding harshly to more and more requests for opium medication. If the doctor is deceived too often, even by just one person, that in turn can lead to disciplinary action against the doctor, by regulatory bodies such as supervisory colleges or boards. The extent of the effect is not known, but nearly every practising clinician in medicine has had to face the problems of patients who laid claim to pain and perhaps still more claim to drugs.

We consider from personal observations of the experiences, attitudes and reactions of doctors, including ourselves, in discussing their patients that this difficulty exists, although it is hard to quantify. It is a factor that contributes to the disparagement of pain, particularly when there is no independent verification for the existence of pain.

\section{RESPONSES}

When a compensation claim may exist, the responses to patients' pain by those appointed to examine and assess may include positive responses but more often provide a range of negative statements. Patients, their doctors or their lawyers are liable to be told that the complaints are subjective and, therefore, not capable of confirmation, that there is no neurological or orthopedic abnormality - other conditions by implication not being provable or being of less certain valuethat the patients exaggerate, that they show signs of behaviour that is 'nonorganic', that their symptoms are actually 'psychogenic' or that they are 'somatizers', and sometimes either that they are malingerers or, as a broad hint, that their behaviour cannot be distinguished from malingering. The misused term 'secondary gain' is often thrown in.

Of course, the possibility of 'faking' always exists. However the rate of diagnosis of such problems is extraordinarily high in people who seem to be doing worse economically, or 
in other ways rather than better by virtue of the alleged 'faking'. It is not very plausible, in case after case, that individuals who often have worked consistently and well for years, enjoyed their jobs, obtained the approval of their workmates and so on, would 'fake' themselves into a situation where if not working, they receive sharply reduced benefits or none, the family situation becomes increasingly tense and strained, debts become overwhelming and they are thrown into poverty. However, when such individuals fail to return to work after a few weeks or months, subsequent to injuries, the rate at which evaluators have tended to judge them as being able to work appears to be extraordinarily high.

In Ontario under current legislation, people injured in a motor vehicle accident and claiming benefits may, after a while, be referred to a designated assessment centre (DAC) by the insurance company. The individuals appointed to operate DACs and evaluate 'clients' are approved by insurance companies, and referrals come from insurance companies only. It is not surprising that only $13 \%$ of patients seen in 1997 and only $17 \%$ of patients seen in 1998 at DACs were accepted as worthy of the benefits requested by their treating health care professionals (50). Such figures for the rejection of claims have become so much the norm that health care practitioners who manage these patients cease to be shocked by such outcomes; however, they are unconscionable nevertheless. Teasell (51) has provided information on the weaknesses of the arguments used to deny chronic pain. As he says, the irony is that current developments help us to understand better than ever before the physiological basis of chronic pain at a time when its denial is being institutionalized.

There are mechanisms of nervous system plasticity that encourage the development of regional pain. Historically, these have been confused with hysteria until the last 20 years or more (52). As well, a series of elegant investigations by Barnsley et al (29) and Lord et al (30) have been regularly ignored by those who reject this position, yet the latter have repeatedly shown, in a variety of ways, using controlled procedures, that pain after cervical sprain injury is closely related to damage to the cervical zygapophyseal joints over $50 \%$ more often than chance expectation. Wallis et al (31) showed, in the same series, that psychological changes associated with whiplash, so called somatization and other psychological complaints, remit dramatically after successful treatment of the pain of whiplash by radiofrequency neurotomy. Likewise, Radanov et al (53) showed that patients suffering from whiplash developed psychological changes subsequent to the whiplash and that these changes were not related to personality features existing before the injury but were related to the intensity of pain at the time of initial injury. Most importantly, personality features at the time of the accident did not predict chronicity.

The so called 'nonorganic' signs of Waddell are themselves behavioural phenomena related to chronic pain. Waddell (54) remarked that they should not be treated as evidence of the presence of psychological illness but simply markers of distress and indicators of a poorer prognosis. In our view, most, if not all of these signs are likely to be a characteristic effect of musculoskeletal or spinal pain due to moderately severe local damage but not involving major nerve damage.

\section{FIBROMYALGIA}

An abundance of evidence has been put forward to demonstrate the pathophysiological basis for fibromyalgia, beginning with the initial observations of sleep disturbance as a significant corollary to the subsequent development of aching pain and discomfort (55), and continuing through the recognition of high levels of substance $\mathrm{P}$ in the cerebrospinal fluid (CSF) of patients with fibromyalgia $(56,57)$ and the association of those high levels with indications of abnormal regional blood flow in the thalamus and the caudate nucleus (58). In fact, an abundance of evidence exists for the concept of central nervous system abnormalities or hypersensitivity in fibromyalgia (59). Additional neurotransmitter changes have been recognized, including an increase in dynorphin of $50 \%$ (60) and a large increase in nerve growth factor in the spinal fluid (61). Despite an ever increasing abundance of scientific evidence that the pain of fibromyalgia has a physiological basis, such information is ignored and replaced with comments such as "fibromyalgia is not a real illness", "I don't believe in fibromyalgia" and similar dismissive attitudes. Individual clinical scientists may have reservations about the diagnosis of fibromyalgia, eg, whether the criteria chosen by the American College of Rheumatology (62) are the best (they probably are), whether the diagnosis is reliable in certain individuals who can gain benefit from making the diagnosis, or that it is not a disabling illness. However, the issue of disability is not the same as that of diagnosis; disability is multifactorial and, like other disabling conditions, fibromyalgia is disabling in only a percentage of sufferers.

Encountering these statements about patients day after day, seeing the misleading quality of much of the literature denying pain, and noting the appallingly callous treatment of injured people occurring with increasing frequency, it is impossible not to conclude that third-party payers have a continuing need for the denial or disparagement of pain as a method of containing costs, and that attitudes evolve within the profession, not only to support patients as we are doing here, but also to hinder them. Hence, patients with chronic pain, already suffering physically and emotionally, have to run a gauntlet of indifferent clinicians, hostile assessors, misinformation and outright harassment in order to receive a fraction of their preinjury income and the cost of extra medical treatments.

\section{INSTITUTIONALIZATION OF THE DENIAL OF CHRONIC PAIN}

There is a widespread tendency in the insurance industry to deny individual claims of pain and injury, and to support this denial by arguing that both in individual cases and in general, medical evidence indicates the occurrence of gross exaggeration. The issue is the extent to which individual claims are denied despite increasing scientific evidence of the legitimacy of these conditions. This denial, which is appropriate in 
the few cases where patients are malingering or excessively embellished, is being used to avoid paying most claims.

Some of that denial was mentioned just above. A further extension can be found in insurance industry initiatives undertaken with respect to medical research and education. In 1995, a task force, appointed by the Société d'assurance automobile du Québec, the provincial government no-fault insurance carrier for Canada's second largest province by population, published a report on cervical flexion extension injuries ('whiplash'), which became widely quoted and used. Part of the report was a 'best evidence' review of available treatments, which in general is good and was widely praised with some justification. Another part of the report comprised a cohort study of all patients compensated for whiplash in 1987, and followed up by the insurer. Figures were presented to the effect that $1.9 \%$ of patients with whiplash alone and $2.9 \%$ of those who had whiplash and other injuries would remain ill at the end of one year $(63,64)$. In Ontario, these figures have been interpreted as indicating that 'whiplash' is a benign condition, to such an extent that individuals who complain of symptoms from it after more than one year probably are making a mistake, to say the least, in attributing their symptoms to an injury. Whiplash has been similarly treated in other provinces widely across Canada, the United States and overseas as well. These figures were not figures for ability to work as tested independently, or figures for the remission of symptoms, but figures based on the insurer's decision as to when to terminate benefits. In this journal, Teasell and Merskey (65) examined the figures presented by the Quebec Task Force (QTF) and found that, although the data were somewhat confusingly presented and hard to follow, it appeared that there was a group called 'recurrences', which, despite some uncertainty about numbers, appeared to be three to four times as large as the original 'whiplash alone' cases, so that instead of $2 \%$ or $3 \%$ being ill at the end of a year, it seemed more likely that $9.5 \%$ were ill. Others who have followed patients and made decisions according to the doctor's evaluation, taking into account both the patient's opinion and the physician's own view of the matter, have found much larger proportions of individuals to be sick or unable to work following significant whiplash injury for which attention was initially required (many rear-end collisions do not provoke complaints of pain, and the follow-up studies are usually based on those cases where pain arose within a short time of the accident [from immediately to 24 to $48 \mathrm{~h}$ ] and were sufficiently bad that patients attended doctors or a hospital emergency department). The other follow-up studies show that $10 \%$ to $45 \%$ of patients are still ill at the end of one year after a troublesome case of whiplash.

Taking the figures and the best evidence synthesis found in the report of the QTF, a group of physicians and others in Vancouver organized an educational event known as the British Columbia Whiplash Initiative (BCWI), dedicated to teaching the findings of the QTF and conclusions to be drawn from their findings to family practitioners and others. BCWI presented a set of educational modules that relied heavily on the QTF in three respects. The recommendations depended on the QTF with respect to the outcome of the cohort study just mentioned - the interpretation of which is flawed. They related to the best evidence synthesis, which is deservedly a well-regarded contribution, and they were generated on the basis of 'consensus recommendations', which the QTF had also provided. However the consensus recommendations were based on 'opinion' and were not comparable with the scientific standard of the best evidence evaluation. The reason for this is simply that there was not enough 'best evidence' available in the field. Even so, it is possible to say that the educational modules of the BCWI were seriously flawed because, not only were they based upon the misleading figures from the QTF, but also they distorted other information in the literature. We provided evidence of this in a previous paper (65).

\section{INSURANCE COMPANIES AND MEDICAL INFORMATION}

The QTF and BCWI are unique in that the insurance industry was directly involved in collating and creating information on medical conditions for use by medical practitioners. The QTF itself was set up by an insurance body, and the BCWI was organized by a foundation established by two insurance companies and an industrial firm. Moreover, the foundation involved in running the program (Physical Medicine Research Foundation) included insurance industry executives on its board, while the organizing committee of five persons for the BCWI World Congress (so called) included among its five members one academic physician, one nonspecialist physician heavily associated with the insurance industry, a director of medical services for a Workers' Compensation Board and a manager for injury management support for the Insurance Corporation of British Columbia.

There is a general issue with respect to industrial support for medical educational activities. Guidelines have been developed by the Canadian Medical Association, with particular reference to the pharmaceutical industry, but apply as well to the insurance industry (66-69). This was accepted for the BCWI in a revision of the self description of the BCWI published on the Internet on March 6, 2000 (70), which states the following.

\section{The Insurance Corporation of British Columbia (ICBC) provided funding for the project by way of an educational grant to PMRF [Physical Medicine Research Foundation] subject to the Canadian Medical Association's guidelines on industry supported Continuing Medical Education (CME).}

The rules in question indicate that any grant must be 'unrestricted', ie, it is placed in the hands of an educational body, which is independent of the granting source, and the original sponsor has no control on any of the part of the content of the meeting. This is to safeguard the independence of doctors who might be paid by drug firms or by insurance companies for the work to be presented.

The insurance industry has a very important legitimate 
interest in injury and its treatment. Issues of safety, accident prevention and minimization of injury when accidents occur matter to the general public and to automobile insurance companies alike. There is every reason to encourage industry participation in these topics. There is a very large problem, however, when insurance bodies are involved in issues connected with the evaluation of medical care. There is a serious risk that they will seek to influence medical opinion in the direction of minimizing the impact or consequences of pain, which will in turn depreciate the disability of individuals.

The attitudes of insurance companies can be very extreme and bring great pressure to individuals to settle cases rather than go to trial. They can also be very distant in the sense of ignoring letters, failure to reply except after long intervals, bland negatives without evidence of justification, statements in justification of their position that amount to stonewalling and so forth. Patients frequently have to wait for years (we have patients whose cases began more than 10 years ago), and so forth. One of our patients was submitted to 17 assessments by an insurance company over a period of four years. This was a lady who was injured in a high speed collision, had needed a diskectomy and subsequently had an obviously stiff back and continuing chronic pain. All of her physicians and health care providers were in agreement regarding the seriousness and impact of her condition. An arbitrator awarded her punitive damages as well as restitution of benefits. A patient whose benefits were paid only by compulsion after arbitration at the end of a period of three years has been without benefits again for a period of nine months because, without significant additional evidence, the insurance company has again ceased payments. Insurance companies have a large social and economic influence on the medical profession. Not to belabour the point, but that influence apparently extends to obtaining many highly favourable and highly questionable medical reports.

\section{HARSH UNPROVED TREATMENTS}

The pressure on patients to accept their pain without further complaint and to return to full normal activity, including hard physical work, is considerable. Apart from behaviourally orientated programs or attitudes such as those disclosed in Back Pain in the Work Place (32), individuals have been urged to return to work after being subjected to unduly aggressive multidisciplinary treatment, especially including cognitive behavioural therapy and operant therapy, after 'work hardening' or after so-called functional restoration. None of these more extreme treatments has provided convincing evidence of reduction of pain or restoration of function in more than a tiny proportion of patients at a level where significant numbers are relieved of commercially important disability. With multidisciplinary treatment, many of the studies use "no treatment controls', ie, those who are refused funding or 'waiting list controls' $(71,72)$. Others have used 'usual treatment', typically defined as 'current best available treatment' for a 'real world' comparison group. But these studies often fail to have large enough sample sizes to detect treatment effects (73). While there is some evidence among these stud- ies that multimodal biopsychosocial treatments that include a cognitive behavioural, or a behavioural component can reduce pain and even improve functional activities in chronic low back pain, there is a lack of evidence, or else the evidence that exists is contradictory with regard to 'vocationally relevant outcomes', ie, 'return to work'.

Work hardening and work conditioning programs evolved in the late 1970s and early 1980s in an attempt to minimize the costs of work-related injuries (74). Lechner (75) reviewed the literature concerning the effectiveness of work hardening and work conditioning programs. Work conditioning programs emphasize physical conditioning and functional activities related to work and are provided on the basis of a single discipline model (75). Work hardening programs, in contrast, are interdisciplinary approaches that address physical and functional needs and use graded work simulations and psychosocial interventions (75). Lechner (75) concluded that there was contradictory evidence that clinic-based work conditioning and work hardening programs improved the return to work rate of more chronically disabled workers with low back pain over the long term. However, there was moderate evidence that work conditioning programs, largely exercise based, were helpful in the subacute stage (four to 12 weeks) in returning patients to work. Most of these studies were not randomized, controlled studies but used a comparison group of patients rejected because of lack of funding or who did not complete the program. Three studies did not have a comparison group at all.

The concept of functional restoration also remains quite popular. Most such programs provide a multidisciplinary approach designed to improve factors contributing to disability apart from the pain itself. Most could be classified as 'work hardening'. The effectiveness of functional restoration programs comprising patients with chronic low back pain has been studied using return to work as the primary outcome measure. Two recent reviews of multidisciplinary rehabilitation programs for chronic low back pain $(76,77)$ concluded that such programs result in significant and favourable changes in employment status, ie, more treated patients return to work. However, all of these studies, including the often quoted studies of Mayer et al (71) and Hazard et al (72) were not randomized, controlled trials but used 'comparison groups' of patients rejected by the assessing physician or denied funding by the insurer. Most of the studies were not blinded, with assessment of outcomes being conducted by individuals with a direct financial stake in a positive outcome.

In the face of such weak evidence that pushing people past their pain tolerance level is truly effective in making any meaningful difference to their pain and suffering or to their return to work, it appears that the drive to enforce conditions of active functional restoration or cure by exercise as exemplified in the instances quoted above is determined more by the interests of the insurer or the prejudices of the physician than by the actual needs of the patients or proper recognition of the intensity of the pain.

A review of the effect of modifications in the workplace, adjusted to the individual worker's disability, supported the 
idea that modified work is effective in facilitating return to work for temporarily and permanently disabled workers (78).

\section{CONCLUSIONS}

The social influences that are conducive to the disparagement of pain by doctors include a decline in recognition of the potential severity of pain because of the introduction of anesthesia as well as concerns over addiction. The latter concerns have been strengthened by the fact that the standing and prestige of doctors, and their legal prerogatives are enhanced by holding control over the use of narcotics by individuals.

Beliefs that patients exaggerate their claims or that the interest in compensation inflates those pains add gravity to the task of controlling narcotics and increase doctors' anxiety, lest they be 'fooled' into prescribing more than is justified. This limits the willingness of doctors to control pain or to acknowledge its intensity fully.

Insurance companies appear also to have intervened increasingly to influence the pattern of thinking held by doctors in ways that suggest much more interest in reducing costs than in minimizing discomfort. This is particularly applicable to the excessive emphasis on behavioural management and cure by exercise, even when the latter hurts increasingly and fails to lead to any type of benefit.

\section{REFERENCES}

1. Hemlow J. Fanny Burney. Selected Letters and Journals. Oxford: Currand \& Press, 1986:127-42.

2. Fülop-Miller R. Triumph Over Pain. (Translated by Paul E, Paul C) New York: The Literary Guild of America Inc, 1938:8.

3. Warren JC. Cases of neuralgia or painful affections of nerves. Boston Med Surg J 1828;1:1-6.

4. Rey R. History of Pain. (Translated by Wallace LE, Cadden JA, Cadden SW) Paris: Éditions la Découverte, 1993.

5. Commission on the Provision of Surgical Services, Report of the Working Party on Pain After Surgery. London: The Royal College of Surgeons of England \& The College of Anaesthetists, September, 1990.

6. Cohen FL. Postsurgical pain relief: patients' status and nurses' medication choices. Pain 1980;9:265-74.

7. Owen H, McMillan V, Rogowski D. Postoperative pain therapy: a survey of patients' expectations and their experiences. Pain 1990;41:303-7.

8. Papper EM, Brodie BB, Rovenstine EA. Postoperative pain: its use in the comparative evaluation of analgesics. Surgery 1952;32:107-9.

9. Dodson ME. The Management of Postoperative Pain. London: Edward Arnold, 1985:21-5.

10. Cassell EJ. The Nature of Suffering. Oxford: Oxford University Press, 1991.

11. Watt-Watson JD. Nurses knowledge of pain issues: A survey. J Pain Symptom Manage 1987;2:207-11.

12. Staats PS. Pain is pain: Why the dichotomy of approach to cancer and non cancer pain? In: MJM Cohen, JN Campbell, eds. Pain Treatment Centers at a Crossroads: A Practical and Conceptual Reappraisal. Progress in Pain Research and Management. Seattle: IASP Press, 1996;7:117-23.

13. Merskey H, Bogduk N, eds. Classification of Chronic Pain: Description of Chronic Pain Syndromes and Definitions of Pain Terms, 2nd edn. Seattle: IASP Press, 1994.

14. Turk DC, Fernandez E. On the putative uniqueness of cancer pain: do psychological principles apply? Behav Res Ther 1990;28:1-13.
15. Peters-Golden H. Breast cancer: Varied perceptions of the social support in the illness experience. Soc Sci Med 1982;16:483-91.

16. Watson CP, Evans RJ, Reed K, Merskey H, Goldsmith L, Warsh J. Amitriptyline versus placebo in postherpetic neuralgia. Neurol (NY) 1982;32:671-3.

17. Erichsen JE. On Railway and Other Injuries of the Nervous System. Philadelphia: Henry C Lea, 1867.

18. Erichsen JE. On Concussion of the Spine, Nervous Shock and other Obscure Injuries to the Nervous System in their Clinical and Medicolegal Aspects. A New and Revised Edition. New York: William Wood $\& \mathrm{Co}, 1886$.

19. Page HW. Injuries of the Spine and Spinal Cord without Apparent Mechanical Lesion and Nervous Shock in their Surgical and Medicolegal Aspects. London: J \& A Churchill, 1883.

20. Reynolds Sir JR. Remarks on paralysis and other disorders of motion and sensation, dependent on idea. Br Med J 1869;ii:483-5. Discussion 378-9.

21. Charcot JM. Clinical lectures on diseases of the nervous system. Delivered at La Salpêtrière, vol 3. (Translated by Savill T). London: The New Sydenham Society, 1889:289.

22. Charcot JM. Clinical lectures on diseases of the nervous system. Delivered at La Salpêtrière, vol 3. (Translated by Savill T). London: The New Sydenham Society, 1889:222-223.

23. Oppenheim H. Die traumatischen Neurosen. Berlin: Hirschwald, 1889. See: Oppenheim H. Textbook of Nervous Diseases for Physicians and Students. (Translated by Bruce ATN). London: Foulis, 1911.

24. Trimble MR. Post-traumatic Neurosis: From Railway Spine to the Whiplash. Chichester: John Wiley \& Sons, 1981.

25. Collie J. Medico/Legal Examinations and the Workman's Compensation Act, 1906. (As amended by subsequent Acts). London: Baillière, Tindall \& Cox, 1922.

26. Kennedy F. The mind of the injured worker. Its effect on disability periods. Compensation Med 1946:119-24.

27. Miller HG. Accident neurosis. Br Med J 1961;i:919-25,992-8.

28. Mendelson G. Not "cured by a verdict". Effect of legal settlement on compensation claimants. Med J Aust 1982;2:132-4.

29. Barnsley L, Lord S, Bogduk N. Comparative local anaesthetic blocks in the diagnosis of cervical zygapophyseal joint pain. Pain 1993;55:99-106.

30. Lord S, Barnsley L, Wallace BJ, MacDonald GJ, Bogduk N. Percutaneous radiofrequency neurotomy for chronic cervical zygapophyseal joint pain. N Engl J Med 1996;335:171-6.

31. Wallis BJ, Lord SM, Bogduk N. Resolution of psychological distress of whiplash patients following treatment by radiofrequency neurotomy: a randomized, double-blind, placebo controlled trial. Pain 1997;73:15-22.

32. Fordyce WE, ed. Back Pain in the Workplace. Management of Disability in Non-specific Conditions. Seattle: IASP Press, 1995.

33. Schrader H, Obelieniene D, Bovim G et al. Natural evolution of the whiplash syndrome outside the medicolegal context. Lancet 1996;347:1207-11.

34. Melzack R. The tragedy of needless pain: A call for social action. Address of the IASP President. In: Dubner R, Gebhart GF, Bond MR, eds. Proceedings of the Vth World Congress on Pain. Amsterdam: Elsevier, 1988:1-11.

35. Jeans ME. The measurement of pain in children. In: R Melzack, ed. Pain Measurement and Assessment. New York: Raven Press, 1983:183-9.

36. Grath PJ, Unruh AN. Pain in Children and Adolescents. Amsterdam: Elsevier, 1987.

37. Eland JM, Anderson JE. The experience of pain in children. In: Jaycox AD, ed. Pain: A Sourcebook for Nurses and Other Health Professionals. Boston: Little, Brown 1977:453-73.

38. Beyer J, DeGood DE, Ashley IC, et al. Patterns of post-operative analgesic use with adults and children. Pain 1983;17:71-81.

39. Schecter NC, Allen DA, Hanson K. The status of pediatric pain control: a comparison of hospital analgesic usage in children and adults. Pediatrics 1986;77:11-5. 
40. Choinière M. Burn pain. In: Wall PD, Melzack R, eds. Textbook of Pain, 2nd edn. Edinburgh: Churchill Livingstone, 1989:402-8.

41. Twycross RG, Lack SA. Symptom control in far advanced cancer. Pain Relief, vol I. New York: Pitman Books, 1983.

42. Taub A. Opioid analgesics in the treatment of chronic intractable pain of non-neoplastic origin. In: Kitahata LM, Collins D, eds. Narcotic Analgesics in Anaesthesiology. Baltimore: Williams \& Wilkins, 1982.

43. Portenoy RK, Foley KM. Chronic use of opioid analgesics in nonmalignant pain: report of thirty-eight cases. Pain 1986;25:171-86.

44. Zenz M, Strumpf M, Tryba, M. Long-term opioid therapy in patients with chronic non-malignant pain. J Symptom Manage 1992;7:69-77.

45. Portenoy RK. Opioid therapy for chronic non-malignant pain. Pain Res Manage 1996;1:17-28.

46. Federation of State Medical Examining Boards of the United States. Model guidelines for the use of controlled substances for the treatment of pain. Euless: Federation of State Medical Boards of the United States, 1998.

47. Jovie R, Ennis J, Gardner-Nix J, et al. Use of opioid analgesics for the treatment of chronic non-cancer pain - a Consensus Statement and Guidelines from the Canadian Pain Society. Pain Res Manage 1998;3:197-208

48. Berridge V, Edwards G. Opium and the people. Opiate use in 19th century England. London: Allen Lane/St Martin's Press, 1981.

49. Knelman J. Twisting in the Wind: The Murderess and the English Press. Toronto: University of Toronto Press, 1998.

50. Legate B. Designated assessment centres and your patient's rehabilitation - statistics show they are likely to favour the insurer's view. Lond Dist Acad Med Newsl 2000;1:10-11.

51. Teasell RW. The denial of chronic pain. Pain Res Manage 1997;2:89-91.

52. Merskey H. Regional pain is rarely hysterical. Arch Neurol 1987;45:915-18.

53. Radanov BP, Sturzenegger M, DeStefano G et al. Relationship between early somatic, radiological, cognitive and psychological findings and outcome during a one-year follow-up in 117 patients suffering from common whiplash. Br J Rheumatol 1994;33:442-8.

54. Waddell G. A new clinical model for the treatment of low back pain. Spine 1987;12:632-44.

55. Smythe HA, Moldofsky H. Two contributions to understanding the 'fibrositis' syndrome. Bull Rheum Dis 1977;28:928-31.

56. Vaeroy H, Helle R, Førre Ø, Kass E, Terenius L. Elevated CSF levels of substance P and high incidence of Raynaud's phenomena in patients with fibromyalgia: new features for diagnosis. Pain 1988;32:21-6.

57. Russell IJ, Orr MD, Littman B, et al. Elevated cerebrospinal fluid levels of substance $P$ in patients with the fibromyalgia syndrome. Arthritis Rheum 1994;11:593-601.

58. Mountz JM, Bradley LA, Modell JG, et al. Fibromyalgia in women. Abnormalities of regional blood flow in the thalamus and the caudate nucleus are associated with low pain threshold levels. Arthritis Rheum 1995;38:926-38.

59. Bennett RM. Chronic widespread pain and the fibromyalgia construct. SIG on Rheumatic Pain Newsletter, January 1999:2-7.

60. Vaeroy H, Nyberg F, Terenius L. No evidence for endorphin deficiency in fibromyalgia following investigation of endorphin fluid
(CSF) dynorphin A and $\mathrm{M}$ endorphin in patients with fibromyalgia (fibrositis syndrome). Pain 1991;46:139-43.

61. Giovengo SL, Russell IJ, Larson AA. Increased concentrations of nerve growth factor in cerebrospinal fluid of patients with fibromyalgia. J Rheumatol 1999;26:1564-9.

62. Wolfe F, Smythe HA, Yunus MB, et al. The American College of Rheumatology 1990 criteria for the classification of fibromyalgia: report of the Multicenter Criteria Committee. Arthritis Rheum 1990;33:160-72.

63. Quebec Task Force on Whiplash-Associated Disorders. WhiplashAssociated Disorders (WAD). Redefining 'Whiplash' and its Management. Quebec: Société de l'assurance automobile du Québec, 1995.

64. Harder S, Veilleux M, Suissa S. The effect of socio-demographic and crash related factors on the prognosis of whiplash. J Clin Epidemiol 1998;51:377-84.

65. Teasell RW, Merskey H. The Quebec Task Force on whiplashassociated disorders and the British Columbia Whiplash Initiative: a study of insurance industry initiatives. Pain Res Manage 1999;4:141-9.

66. White M, Richman J, Haldeman S. The Quebec Task Force in Whiplash Associated Disorders. Pain Res Manage 1999;4:161-2.

67. Merskey H, Teasell RW. The Quebec Task Force on Whiplashassociated Disorders: Reply to White et al. Pain Res Manage 1999;4:162-3. (Lett)

68. Barron SR, Ho K, Anton H, Lubin S. The Quebec Task Force on Whiplash-Associated Disorders. A study of insurance industry initiatives. Pain Res Manage 2000;5:11-12. (Lett)

69. Merskey H, Teasell R. The Quebec Task Force on WhiplashAssociated Disorders. A study of insurance industry initiatives. Pain Res Manage 2000;5:12-13. (Lett)

70. British Columbia Whiplash Initiative. $<$ http://www.healthsciences.ubc.ca/whiplash.bc $>$ (Version current at March 6, 2000)

71. Mayer TC, Gatchel RJ, Mayer H, et al. A prospective two-year study of functional restoration in industrial low back injury. An objective assessment procedure. JAMA 1987;258:1763-7.

72. Hazard RG, Fenwick JW, Kalisch SM, et al. Functional restoration with behavioral support: a one-year prospective study of patients with chronic low back pain. Spine 1989;14:157-61.

73. Workplace Safety \& Insurance Board, Ontario. Toronto: Report of the Chronic Pain Expert Advisory Panel, February 1, 2000.

74. Helms-Williams P. Industrial rehabilitation: developing guidelines. Magazine of Physical Therapy 1993;1:65-8.

75. Lechner DE. Work hardening and work conditioning interventions: Do they affect disability? Phys Ther 1994;74:471-93.

76. Cutler RB, Fishbain DA, Rosomoff HL, et al. Does non-surgical pain center treatment of chronic pain return patients to work? A review and meta-analysis of the literature. Spine 1994;19:643-52.

77. Fuerstein M, Zastowny TR. Occupational rehabilitation: Multidisciplinary management of work-related musculoskeletal pain and disability. In: Gatchel R, Tunk DC, eds. Psychological Approaches to Pain Management. A Practitioner's Handbook. London: The Guilford Press, 1999:458-85.

78. Krause N, Kasinger LK, Neuhauser F. Modified work and return to work: A review of the literature. J Occup Rehabil 1998;8:113-39. 


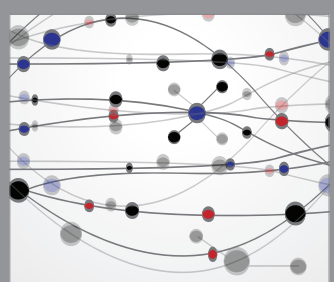

The Scientific World Journal
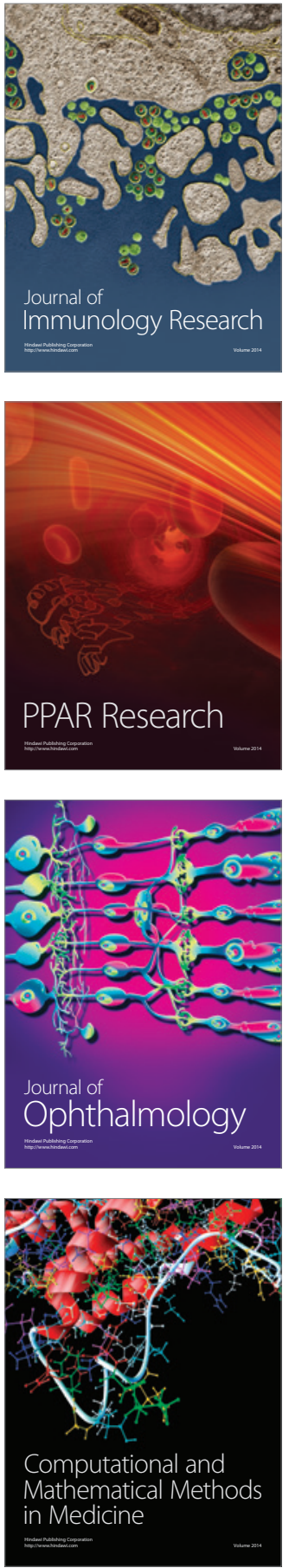

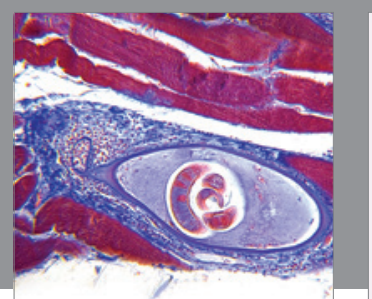

Gastroenterology Research and Practice

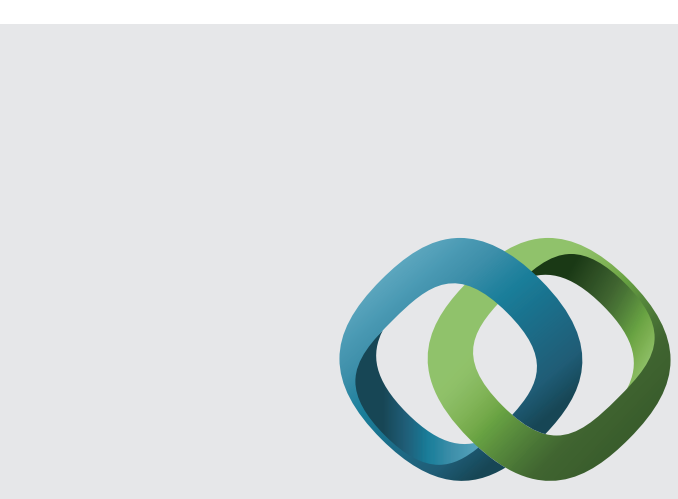

\section{Hindawi}

Submit your manuscripts at

http://www.hindawi.com
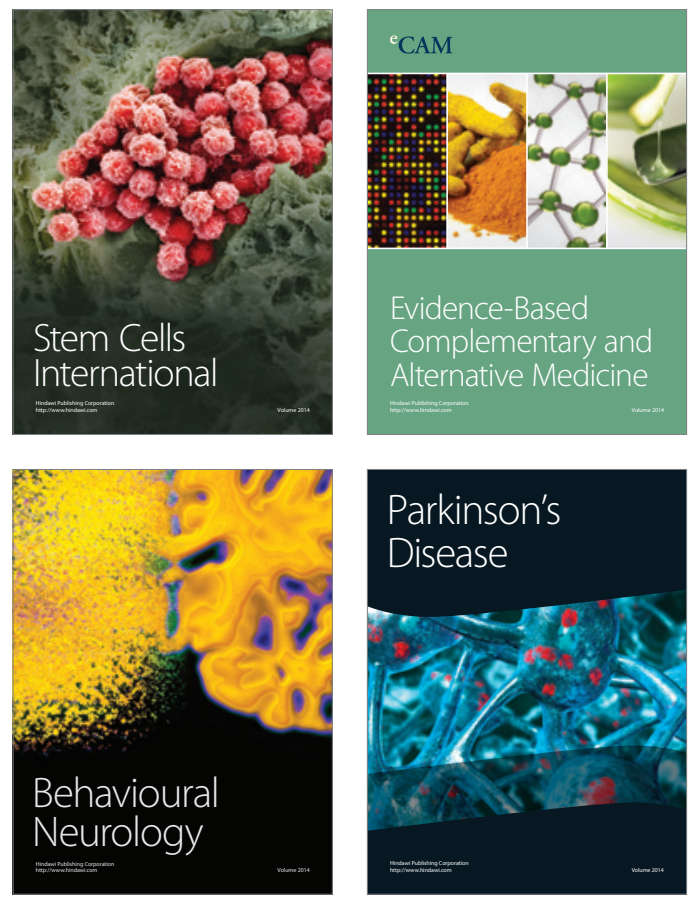
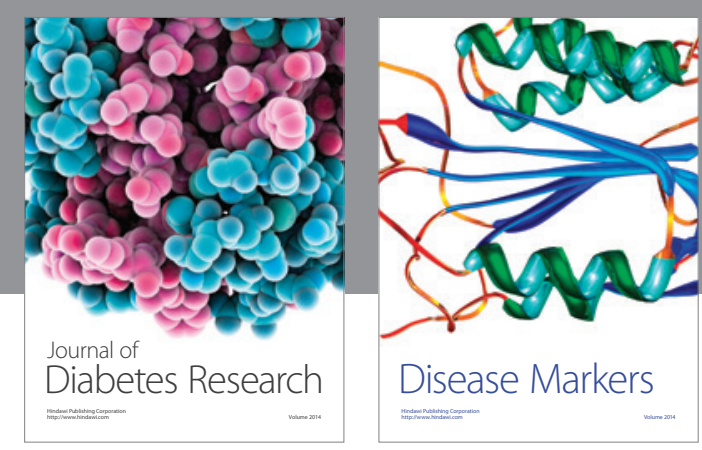

Disease Markers
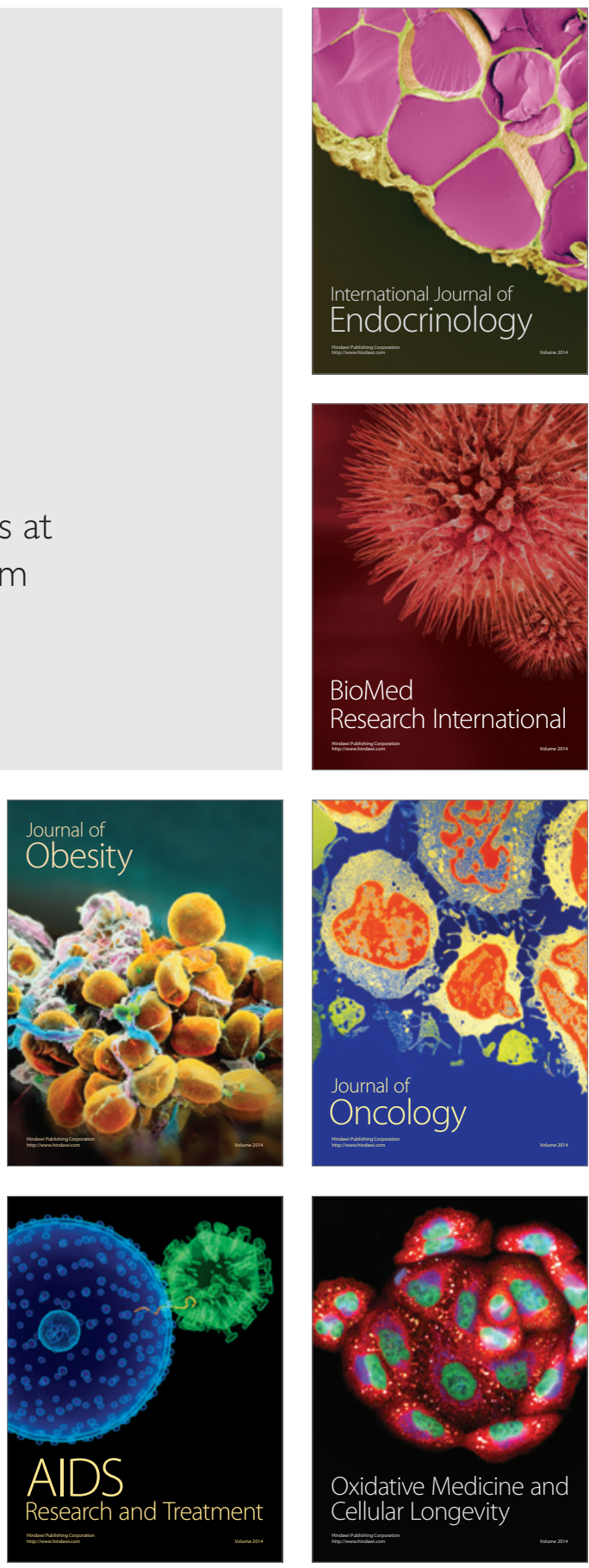